\title{
Association Among Sentinel Surveillance, Meteorological Factors, and Infectious Disease in Gwangju, Korea
}

\section{You Hyun Joung}

Dankook University Graduate School of Medicine

\section{Taesu Jang}

Dankook University

Jae Kyung Kim ( $\square$ nerowolf2@dankook.ac.kr)

Dankook University College of Health Sciences https://orcid.org/0000-0002-1534-563X

\section{Research Article}

Keywords: Meteorological factors, Sentinel Surveillance System, epidemiology, Infectious Disease, Bacterial Gastroenteritis, Viral gastroenteritis

Posted Date: July 9th, 2021

DOl: https://doi.org/10.21203/rs.3.rs-658178/v1

License: (a) (1) This work is licensed under a Creative Commons Attribution 4.0 International License. Read Full License

Version of Record: A version of this preprint was published at Environmental Science and Pollution Research on October 20th, 2021. See the published version at https://doi.org/10.1007/s11356-02117085-2. 


\section{Abstract}

\section{Introduction:}

The outbreak of new infectious diseases is threatening human survival. Transmission of such diseases is determined by several factors, with climate being a very important factor. This study was conducted to assess the correlation between the occurrence of infectious diseases and climatic factors using data from the Sentinel Surveillance System and meteorological data from Gwangju, Jeollanam-do, Republic of Korea.

\section{Result}

The climate of Gwangju from June to September is humid, with this city having the highest average temperature, whereas that from December to February is cold and dry. Infection rates of Salmonella (Temperature: $r=0.710^{\star *}$; Relative humidity: $\left.r=0.669^{\star *}\right)$, E. coli $(r=0.617 * * ; r=0.626 * \star)$, Rotavirus $\left(r=-0.408^{* *} ; r=-0.618^{* *}\right)$, Norovirus $\left(r=-0.463^{* *} ; r=-0.316^{* *}\right)$, Influenza virus $\left(r=-0.726^{* *} ; r=-0.672^{\star *}\right)$, Coronavirus ( $\left.r=-0.684^{\star *} ; r=-0.408^{\star *}\right)$, and Coxsackievirus $\left(r=0.654^{\star *} ; r=0.548^{\star \star}\right)$ have been shown to have a high correlation with seasonal changes, specifically in these meteorological factors.

\section{Discussion \& Conclusions:}

Pathogens showing distinct seasonality in the occurrence of infection were observed, and there was a high correlation with the climate characteristics of Gwangju. In particular, viral diseases show strong seasonality, and further research on this matter is needed. Due to the current COVID-19 pandemic, quarantine and prevention have become important to block the spread of infectious diseases. For this purpose, studies that predicts infectivity through various types of data related to infection are important.

\section{Introduction}

Currently, the incidence of infectious diseases is decreasing in developed countries, but infectious diseases are still an important cause of death and disease in underprivileged and developing countries with poor sanitation (WHO 2007). The transmission of infectious diseases is determined by a number of factors, such as social, economic, and ecological conditions, access to medical services, and human innate immunity (Jones et al. 2008). The agents of various infectious diseases and the growth rates of reservoir species and pathogens are known to be sensitive to climatic conditions (McMichael et al. 2006), and suitable weather conditions for their survival and reproduction facilitate their spread (WHO 2003).

Discussions on the issue of climate change have been active in recent years, wherein the World Health Organization (WHO) went so far to state that "Climate change is the greatest challenge of the $21 \mathrm{st}$ century, threatening all aspects of the society in which we live" (Campbell-Lendrum et al. 2018). In 
addition, the US Centre for Disease Control and Prevention (CDC) reports that abnormal weather phenomena caused by global climate change are damaging, affecting society, economy, and politics, and have a great impact on the health of humanity, especially in the area of infectious diseases (U.S. CDC 2019).

Therefore, climate change is also a major issue in the health sector. To explain the relationship between climate change and infectious diseases, many studies have been conducted on the spread of infectious diseases, reproduction rates, and host migration based on changes in temperature and in the balance of the ecosystem (Lafferty 2009). Climate change affects the incidence, prevalence, and distribution of infectious diseases, and the uncertainty is expected to be high. In this regard, we proposed the construction of an integrated network of environmental and epidemiological data (Semenza and Menne, 2009). In particular, climate change and increased climate variability are more likely to affect vector-borne diseases (Gage et al., 2008).

Although many studies have explained seasonal fluctuations in specific infectious diseases, a few studies have investigated long-term trends in climate and various disease group involvement. Therefore, this study aimed to evaluate whether infectious disease outbreaks in Korea and climate change are related by analyzing data on infectious diseases and meteorological factors that occurred in a region in Korea.

\section{Materials And Methods}

\section{Infectious Disease Data}

Infectious disease occurrence data from 2016 to 2019 were obtained from the Gwangju-si, Jeollanam-do, Republic of Korea sample surveillance infectious disease data, published on the Infectious Disease Portal of the Korea Disease Control and Prevention Agency. In Table 1, sentinel surveillance infectious disease refers to an infectious disease that is continuously monitored and its data continuously collected by designating sample organizations for infectious diseases, designated by the Act on the Prevention and Management of Infectious Diseases in Korea. Early detection is very important to the monitoring and analyses of epidemic incidence rates and trends, in order to effectively respond to outbreaks and provide rapid information about the disease. The Sentinel Surveillance System is an infectious disease management system. Sentinel surveillance data are used in Gwangju, wherein the collection of data is based on reports of the competent medical institutions (comprising both laboratory examinations and physician's diagnosis) and examination results are collated and analyzed at the Gwangju Research Institute for Public Health and Environment. When detected, infectious diseases are reported to the website of the sentinel surveillance infectious diseases (http://is.cdc.go.kr) within 7 days. In addition, this study was exempted from deliberation in the Dankook University Institutional Review Board (approval number: DKU 2021-03-060). 
Table 1

Sentinel surveillance infectious disease in Korea

\begin{tabular}{|c|c|c|c|}
\hline $\begin{array}{l}\text { Surveillance } \\
\text { System }\end{array}$ & Division & \multicolumn{2}{|l|}{ Infectious disease name } \\
\hline \multirow{14}{*}{$\begin{array}{l}\text { Sentinel } \\
\text { Surveillance } \\
\text { System }\end{array}$} & Group 3 & \multicolumn{2}{|l|}{ Influenza $(A, B)$} \\
\hline & Group 5 & \multicolumn{2}{|c|}{$\begin{array}{l}\text { Ascariasis, Trichuriasis, Enterobiasis, Clonorchiasis, } \\
\text { Paragonimiasis, Metagonimiasis }\end{array}$} \\
\hline & Designated & \multicolumn{2}{|c|}{ Hand, foot, and mouth disease } \\
\hline & & \multirow[t]{3}{*}{$\begin{array}{l}\text { Sexually transmitted } \\
\text { diseases }\end{array}$} & $\begin{array}{l}\text { Gonorrhea, Chlamydial } \\
\text { infection }\end{array}$ \\
\hline & & & Chancroid, Genital herpes \\
\hline & & & Condyloma acuminata \\
\hline & & \multirow{4}{*}{$\begin{array}{l}\text { Health care-associated } \\
\text { infections }\end{array}$} & VRE \\
\hline & & & MRSA \\
\hline & & & MRPA \\
\hline & & & MRAB \\
\hline & & \multirow[t]{4}{*}{$\begin{array}{l}\text { Sentinels in infections } \\
\text { surveillance }\end{array}$} & $\begin{array}{l}\text { Gastrointestinal } \\
\text { infections }\end{array}$ \\
\hline & & & $\begin{array}{l}\text { Acute respiratory } \\
\text { infections }\end{array}$ \\
\hline & & & $\begin{array}{l}\text { Imported parasitic } \\
\text { infections }\end{array}$ \\
\hline & & & Enterovirus Infection \\
\hline $\begin{array}{l}\text { Supplementary } \\
\text { Surveillance }\end{array}$ & & & Ophthalmologic Disease \\
\hline
\end{tabular}

\section{Climate data}

The climate data for the Gwangju region used in this study were provided by the weather data opening portal of the Korea Meteorological Administration. Meteorological factors used were the monthly average temperature, relative humidity (RH), amount of precipitation, and particulate matter concentration.

\section{Classification and definition of infections}

The period between January 2016 to December 2019 was subject to the reporting of gastrointestinal infections, acute respiratory infections, and enterovirus infections in the Gwangju Research Institute for Public Health and Environment sentinel surveillance of infectious diseases. Gastrointestinal infections are classified into bacterial gastroenteritis (8,671 cases) and viral gastroenteritis (8,668 cases), while 
acute respiratory infections are classified as viral respiratory infections $(9,823$ cases $)$ and enterovirus infections (3,715 cases).

\section{Study method}

Cross-analysis with pathogenic disease data was performed using the infectious disease occurrence data (monthly and yearly) and meteorological data from the same period obtained from the Korea Meteorological Administration. A correlation analysis was conducted to determine the relationship between meteorological factors and disease occurrence. The appropriate sample size for this study was calculated using G*Power version 3.1, and the size that was calculated was 588 with a power of 0.95 . Given that the total sample size of this study was 30,877 , we believe that the sample size to be satisfactory. The Kolmogorov-Smirnov test was used to assess the normality of distribution of continuous variables, and statistical analysis was performed at a significance level of 0.05 , using SPSS version 21.0 (SPSS Inc., Chicago, IL, USA).

\section{Result}

\section{General characteristics of the infectious disease outbreak}

Table 2 shows the distribution of infectious diseases and meteorological factors from 2016 to 2019, with 30,877 suspected cases of infectious diseases and 9,051 detected pathogens. Among the 8,671 cases (28.1\%) suspected of bacterial gastroenteritis, 1,561 cases $(17.2 \%)$ were detected by examining the sample specimen (stool, rectal smear, etc.), and the most frequently detected pathogens were Salmonella (non-typhoidal, 525 cases, $33.6 \%$ ), E. coli (502 cases, $32.2 \%)$, C. jejuni (215 cases, $13.8 \%$ ), and S. aureus (200 cases, $12.8 \%$ ). Of the 8,668 cases (28.1\%) suspected of viral gastroenteritis, 2,264 cases $(25.0 \%)$ were detected by examining the sample specimen (stool, rectal smear, etc.), and norovirus (955 cases, $42.2 \%$ ) and rotavirus (797 cases, $35.2 \%$ ) were the most frequently detected pathogens. 
Table 2

General characteristics of the sentinel surveillance infectious disease

\begin{tabular}{|c|c|c|c|c|c|}
\hline \multirow[t]{2}{*}{ Classification } & \multicolumn{4}{|l|}{ Year } & \multirow[t]{2}{*}{ Total } \\
\hline & 2016 & 2017 & 2018 & 2019 & \\
\hline $\begin{array}{l}\text { Number of tests for bacterial } \\
\text { gastroenteritis }\end{array}$ & $\begin{array}{l}1630 \\
\left(18.8^{\star}\right)\end{array}$ & $\begin{array}{l}2220 \\
(25.6)\end{array}$ & $\begin{array}{l}2525 \\
(29.1)\end{array}$ & $\begin{array}{l}2296 \\
(26.5)\end{array}$ & $\begin{array}{l}8671 \\
(28.1)\end{array}$ \\
\hline Number of detections & $\begin{array}{l}343 \\
(22.0)\end{array}$ & $\begin{array}{l}412 \\
(26.4)\end{array}$ & $\begin{array}{l}428 \\
(27.4)\end{array}$ & $\begin{array}{l}378 \\
(24.2)\end{array}$ & $\begin{array}{l}1561 \\
(17.2)\end{array}$ \\
\hline Salmonella & $\begin{array}{l}104 \\
(30.3)\end{array}$ & $\begin{array}{l}157 \\
(38.1)\end{array}$ & $\begin{array}{l}136 \\
(31.8)\end{array}$ & $\begin{array}{l}128 \\
(33.9)\end{array}$ & $\begin{array}{l}525 \\
(33.6)\end{array}$ \\
\hline E. coli & $96(28.0)$ & $\begin{array}{l}130 \\
(31.6)\end{array}$ & $\begin{array}{l}135 \\
(31.5)\end{array}$ & $\begin{array}{l}141 \\
(37.3)\end{array}$ & $\begin{array}{l}502 \\
(32.2)\end{array}$ \\
\hline Shigella spp & $5(1.5)$ & $0(0.0)$ & $3(0.7)$ & $1(0.3)$ & $9(0.6)$ \\
\hline Vibrio parahemolyticus & $0(0.0)$ & $1(0.2)$ & $2(0.5)$ & $3(0.8)$ & $6(0.4)$ \\
\hline Campylobacter jejuni, C. coli & $34(9.9)$ & $44(10.7)$ & $87(20.3)$ & $50(13.2)$ & $\begin{array}{l}215 \\
(13.8)\end{array}$ \\
\hline Staphylococcus aureus & $79(23.0)$ & $47(11.4)$ & $41(9.6)$ & $33(8.7)$ & $\begin{array}{l}200 \\
(12.8)\end{array}$ \\
\hline Yersinia enterocolitica & $2(0.6)$ & $7(1.7)$ & $0(0.0)$ & $7(1.9)$ & $16(1.0)$ \\
\hline Bacillus cereus & $17(5.0)$ & $20(4.9)$ & $20(4.7)$ & $11(2.9)$ & $68(4.4)$ \\
\hline Clostridium perfringens & $6(1.7)$ & $5(1.2)$ & $4(0.9)$ & $4(1.0)$ & $19(1.2)$ \\
\hline Listeria monocytogenes & $0(0.0)$ & $1(0.2)$ & $0(0.0)$ & $0(0.0)$ & $1(0.0)$ \\
\hline $\begin{array}{l}\text { Number of tests for viral } \\
\text { gastroenteritis }\end{array}$ & $\begin{array}{l}1630 \\
(18.8)\end{array}$ & $\begin{array}{l}2220 \\
(25.6)\end{array}$ & $\begin{array}{l}2522 \\
(29.1)\end{array}$ & $\begin{array}{l}2296 \\
(26.5)\end{array}$ & $\begin{array}{l}8668 \\
(28.1)\end{array}$ \\
\hline Number of detections & $\begin{array}{l}422 \\
(18.6)\end{array}$ & $\begin{array}{l}696 \\
(30.7)\end{array}$ & $\begin{array}{l}592 \\
(26.1)\end{array}$ & $\begin{array}{l}554 \\
(24.5)\end{array}$ & $\begin{array}{l}2264 \\
(25.0)\end{array}$ \\
\hline Rotavirus & $77(17.4)$ & $\begin{array}{l}176 \\
(25.3)\end{array}$ & $\begin{array}{l}169 \\
(28.5)\end{array}$ & $\begin{array}{l}375 \\
(67.7)\end{array}$ & $\begin{array}{l}797 \\
(35.2)\end{array}$ \\
\hline Adenovirus & $52(11.8)$ & $47(6.8)$ & $49(8.3)$ & $\begin{array}{l}109 \\
(19.6)\end{array}$ & $\begin{array}{l}257 \\
(11.3)\end{array}$ \\
\hline Astrovirus & $29(6.6)$ & $55(7.9)$ & $76(12.8)$ & $10(1.8)$ & $170(7.5)$ \\
\hline Norovirus & $\begin{array}{l}247 \\
(55.9)\end{array}$ & $\begin{array}{l}404 \\
(58.0)\end{array}$ & $\begin{array}{l}277 \\
(46.8)\end{array}$ & $27(4.9)$ & $\begin{array}{l}955 \\
(42.2)\end{array}$ \\
\hline Sapovirus & $17(3.8)$ & $14(2.0)$ & $21(3.6)$ & $33(6.0)$ & $85(3.8)$ \\
\hline
\end{tabular}




\begin{tabular}{|c|c|c|c|c|c|}
\hline \multirow[t]{2}{*}{ Classification } & \multicolumn{4}{|l|}{ Year } & \multirow[t]{2}{*}{ Total } \\
\hline & 2016 & 2017 & 2018 & 2019 & \\
\hline $\begin{array}{l}\text { Number of tests for viral respiratory } \\
\text { infections }\end{array}$ & $\begin{array}{l}2130 \\
(21.7)\end{array}$ & $\begin{array}{l}3306 \\
(33.7)\end{array}$ & $\begin{array}{l}2842 \\
(28.9)\end{array}$ & $\begin{array}{l}1545 \\
(15.7)\end{array}$ & $\begin{array}{l}9823 \\
(31.8)\end{array}$ \\
\hline Number of detections & $\begin{array}{l}734 \\
(19.2)\end{array}$ & $\begin{array}{l}1166 \\
(30.5)\end{array}$ & $\begin{array}{l}932 \\
(24.4)\end{array}$ & $\begin{array}{l}992 \\
(25.9)\end{array}$ & $\begin{array}{l}3824 \\
(42.3)\end{array}$ \\
\hline Influenza virus & $\begin{array}{l}206 \\
(28.0)\end{array}$ & $\begin{array}{l}236 \\
(20.3)\end{array}$ & $\begin{array}{l}143 \\
(15.4)\end{array}$ & $\begin{array}{l}169 \\
(17.0)\end{array}$ & $\begin{array}{l}754 \\
(19.7)\end{array}$ \\
\hline Adenovirus & $71(9.7)$ & $\begin{array}{l}126 \\
(10.8)\end{array}$ & $\begin{array}{l}165 \\
(17.7)\end{array}$ & $\begin{array}{l}215 \\
(21.7)\end{array}$ & $\begin{array}{l}577 \\
(15.1)\end{array}$ \\
\hline PIV & $66(9.0)$ & $\begin{array}{l}161 \\
(13.8)\end{array}$ & $93(10.0)$ & $\begin{array}{l}104 \\
(10.5)\end{array}$ & $\begin{array}{l}424 \\
(11.1)\end{array}$ \\
\hline RSV & $57(7.8)$ & $\begin{array}{l}127 \\
(10.9)\end{array}$ & $83(8.9)$ & $71(7.2)$ & $338(8.8)$ \\
\hline Coronavirus & $77(10.5)$ & $69(5.9)$ & $89(9.5)$ & $47(4.7)$ & $282(7.4)$ \\
\hline Rhinovirus & $\begin{array}{l}165 \\
(22.5)\end{array}$ & $\begin{array}{l}281 \\
(24.1)\end{array}$ & $\begin{array}{l}234 \\
(25.1)\end{array}$ & $\begin{array}{l}249 \\
(25.1)\end{array}$ & $\begin{array}{l}929 \\
(24.3)\end{array}$ \\
\hline HBoV & $27(3.7)$ & $40(3.4)$ & $27(2.9)$ & $43(4.3)$ & $137(3.6)$ \\
\hline HMPV & $65(8.8)$ & $\begin{array}{l}126 \\
(10.8)\end{array}$ & $98(10.5)$ & $94(9.5)$ & $\begin{array}{l}383 \\
(10.0)\end{array}$ \\
\hline $\begin{array}{l}\text { Number of tests for enterovirus } \\
\text { infections }\end{array}$ & $\begin{array}{l}861 \\
(23.2)\end{array}$ & $\begin{array}{l}967 \\
(26.0)\end{array}$ & $\begin{array}{l}1113 \\
(30.0)\end{array}$ & $\begin{array}{l}774 \\
(20.8)\end{array}$ & $\begin{array}{l}3715 \\
(12.0)\end{array}$ \\
\hline Number of detections & $\begin{array}{l}464 \\
(33.1)\end{array}$ & $\begin{array}{l}298 \\
(21.2)\end{array}$ & $\begin{array}{l}370 \\
(26.4)\end{array}$ & $\begin{array}{l}270 \\
(19.3)\end{array}$ & $\begin{array}{l}1402 \\
(15.5)\end{array}$ \\
\hline Echovirus & $\begin{array}{l}171 \\
(36.9)\end{array}$ & $16(5.4)$ & $\begin{array}{l}126 \\
(34.0)\end{array}$ & $58(21.5)$ & $\begin{array}{l}371 \\
(26.5)\end{array}$ \\
\hline Coxsackievirus & $\begin{array}{l}107 \\
(23.1)\end{array}$ & $\begin{array}{l}167 \\
(56.0)\end{array}$ & $\begin{array}{l}146 \\
(39.5)\end{array}$ & $0(0.0)$ & $\begin{array}{l}420 \\
(30.0)\end{array}$ \\
\hline Enterovirus & $3(0.6)$ & $6(2.0)$ & $13(3.5)$ & $76(28.1)$ & $98(7.0)$ \\
\hline Poliovirus & $0(0.0)$ & $0(0.0)$ & $0(0.0)$ & $50(18.5)$ & $50(3.5)$ \\
\hline untypable & $\begin{array}{l}183 \\
(39.4)\end{array}$ & $\begin{array}{l}109 \\
(36.6)\end{array}$ & $85(23.0)$ & $86(31.9)$ & $\begin{array}{l}463 \\
(33.0)\end{array}$ \\
\hline Total number of tests & $\begin{array}{l}6251 \\
(20.2)\end{array}$ & $\begin{array}{l}8713 \\
(28.2)\end{array}$ & $\begin{array}{l}9002 \\
(29.2)\end{array}$ & $\begin{array}{l}6911 \\
(22.4)\end{array}$ & 30877 \\
\hline Total number of detection & $\begin{array}{l}1963 \\
(21.7)\end{array}$ & $\begin{array}{l}2572 \\
(28.4)\end{array}$ & $\begin{array}{l}2322 \\
(25.7)\end{array}$ & $\begin{array}{l}2194 \\
(24.2)\end{array}$ & 9051 \\
\hline * mean & & & & & \\
\hline
\end{tabular}




\begin{tabular}{|llllll|}
\hline Classification & \multicolumn{2}{c}{ Year } & \multicolumn{3}{c|}{ Total } \\
\cline { 2 - 5 } & $\mathbf{2 0 1 6}$ & $\mathbf{2 0 1 7}$ & $\mathbf{2 0 1 8}$ & $\mathbf{2 0 1 9}$ & \\
\hline Meteorological factor & & & & & \\
\hline Temperature $\left({ }^{\circ} \mathrm{C}\right)$ & 15.0 & 14.6 & 14.6 & 14.7 & 14.7 \\
\hline Atmospheric Pressure $(\mathrm{hPa})$ & 1008.1 & 1008.4 & 1008.3 & 1008.0 & 1008.2 \\
\hline Relative Humidity $(\%)$ & 71.9 & 68.7 & 70.6 & 69.2 & 70.1 \\
\hline Precipitation $(\mathrm{mm})$ & 123.5 & 78.1 & 119.0 & 90.5 & 102.8 \\
\hline Wind chill Temperature $\left({ }^{\circ} \mathrm{C}\right)$ & 14.6 & 14.2 & 14.2 & 14.3 & 14.4 \\
\hline Particulate Matter $\left(\mathbb{\nabla} / \mathrm{m}^{3}\right)$ & 36.2 & 34.1 & 29.0 & 29.8 & 32.2 \\
\hline * mean & & & & & \\
\hline
\end{tabular}

Viral respiratory infections were detected most frequently during the study period. Of the 9,823 suspected viral respiratory infection cases (31.8\%), 1,561 cases (42.3\%) were detected pathogens, and rhinovirus (929 cases, $24.3 \%$ ), influenza virus (754 cases, 19.7\%), and adenovirus (577 cases, $15.1 \%$ ) were the most frequently detected pathogens. Among the 3,715 cases (12.0\%) suspected of enterovirus infections, 1,402 cases $(15.5 \%)$ were detected as viruses, wherein Coxsackievirus (420 cases, $30.0 \%$ ) and echovirus (371 cases, $26.5 \%)$ were the most frequently detected. There were also $463(33.0 \%)$ cases of viruses of unknown type. Looking at the meteorological factors during the same period, temperature was $14.6 \sim$ $15.0^{\circ} \mathrm{C}, \mathrm{RH}(\%)$ was $68.7 \sim 71.9 \%$, precipitation was $78.1 \sim 123.5 \mathrm{~mm}$, and particulate matter concentration was observed to be $29.0 \sim 36.2 \mu \mathrm{g} / \mathrm{m}^{3}$.

\section{Characteristics of seasonal meteorological factors and changes in infectious disease occurrence}

In Fig. 1, meteorological factors and infectious disease epidemic characteristics are shown for each season, with the average temperature, $\mathrm{RH}$, and precipitation being highest from July $\left(27.1^{\circ} \mathrm{C}, 84 \%, 210.0\right.$ $\mathrm{mm}$, respectively) to August $\left(27.6^{\circ} \mathrm{C}, 80 \%, 205.9 \mathrm{~mm}\right.$, respectively). During this period, Salmonella (75,125 cases), E. coli (78,134 cases), C. jejuni and C. coli (4,141 cases), and Coxsackievirus $(110,100$ cases) were found to have the highest incidence than in any other period. The coldest and driest months, along with low precipitation, were December $\left(3.7^{\circ} \mathrm{C}, 64.3 \%, 34.4 \mathrm{~mm}\right.$, respectively), January $\left(1.1^{\circ} \mathrm{C}, 65.3 \%\right.$, $29.2 \mathrm{~mm}$, respectively), and February $\left(2.9^{\circ} \mathrm{C}, 58.0 \%, 36.5 \mathrm{~mm}\right.$, respectively). During this period,

Salmonella (December: 11 cases, January: 16 cases, and February: 18 cases), E. coli (31, 14, 16 cases), $C$. jejuni and $C$. coli $(12,10,17$ cases), and Coxsackievirus (9, 1, 2 cases) showed low detection rates. However, there were also infectious disease pathogens observed to be prevalent in winter, such as rotavirus, norovirus, influenza virus, and coronavirus. Rotavirus was detected at low levels from July to November, with the lowest detection rate in August (four cases) and the highest detection rate in March (188 cases). Norovirus was prevalent from November to May of the following year, with the lowest 
detection rate in July (25 cases) and the highest detection rate in December (229 cases). Similarly, influenza virus (164 cases) and coronavirus (62 cases) were also detected with the highest number of pathogens in December and influenza virus detection rates were low from June to October $(4,3,1,1$, and 1 cases, respectively). Coronavirus detection rates were low from June to July (2, 3 cases, respectively).

\section{Correlation between infectious disease prevalence and meteorological factors}

Table 3 shows the correlation between monthly meteorological factors and disease-causing pathogens using Pearson's correlation coefficient. Salmonella (Temperature: $r=0.710, p<0.01 ; R H: r=0.669, p<0.01$; precipitation: $r=0.659, p<0.01$; particulate matter: $r=-0.508, p<0.01)$, E. coli $(r=0.617, p<0.01 ; r=0.626$, $p<0.01 ; r=0.593, p<0.01 ; r=-0.672, p<0.01)$, and Campylobacter jejuni and $C$. coli $(r=0.458, p<0.01 ; r=$ $0.304, p<0.05 ; r=0.431, p<0.01 ; r=-0.330, p<0.05)$, among other bacterial gastroenteritis pathogens, were observed to have a positive correlation with meteorological factors (temperature, $\mathrm{RH}$, and precipitation). 
Table 3

Correlations between incidences of the infectious diseases and monthly mean values of meteorological factors

\begin{tabular}{|c|c|c|c|c|}
\hline Classification & $\begin{array}{l}\text { Temperature } \\
\left({ }^{\circ} \mathrm{C}\right)\end{array}$ & $\begin{array}{l}\text { Relative } \\
\text { Humidity (\%) }\end{array}$ & $\begin{array}{l}\text { Precipitation } \\
(\mathrm{mm})\end{array}$ & $\begin{array}{l}\text { Particulate Matter } \\
\left(\mathbb{\nabla} / \mathrm{m}^{3}\right)\end{array}$ \\
\hline Salmonella & $0.710 * \star$ & $0.669 * *$ & $0.659 * *$ & $-0.508 * *$ \\
\hline E. coli & $0.617^{* \star}$ & $0.626 * \star$ & $0.593 * *$ & $-0.672 * *$ \\
\hline Shigella spp & 0.164 & 0.212 & $0.378 * \star$ & -0.192 \\
\hline $\begin{array}{l}\text { Vibrio } \\
\text { parahemolyticus }\end{array}$ & 0.081 & 0.140 & 0.102 & -0.222 \\
\hline $\begin{array}{l}\text { Campylobacter jejuni, } \\
\text { C. coli }\end{array}$ & $0.458 * *$ & $0.304^{*}$ & $0.431 * *$ & $-0.330 *$ \\
\hline $\begin{array}{l}\text { Staphylococcus } \\
\text { aureus }\end{array}$ & 0.245 & 0.249 & $0.371 * *$ & 0.032 \\
\hline Yersinia enterocolitica & -0.020 & -0.132 & -0.182 & 0.007 \\
\hline Bacillus cereus & $0.399 * *$ & 0.276 & 0.153 & -0.283 \\
\hline $\begin{array}{l}\text { Clostridium } \\
\text { perfringens }\end{array}$ & 0.156 & 0.095 & 0.090 & -0.085 \\
\hline $\begin{array}{l}\text { Listeria } \\
\text { monocytogenes }\end{array}$ & 0.006 & -0.168 & -0.070 & 0.193 \\
\hline Rotavirus & $-0.408 * *$ & $-0.618 * *$ & $-0.336 *$ & $0.321 *$ \\
\hline Adenovirus & -0.042 & -0.068 & -0.038 & -0.111 \\
\hline Astrovirus & 0.269 & 0.250 & $0.376 * \star$ & -0.273 \\
\hline Norovirus & $-0.463 * *$ & $-0.316^{*}$ & $-0.351 *$ & 0.191 \\
\hline Sapovirus & $0.348 *$ & $0.379 * *$ & 0.262 & $-0.308 *$ \\
\hline Influenza virus & -0.726 ** & $-0.672 * \star$ & $-0.498 * *$ & 0.478 ** \\
\hline Adenovirus & -0.130 & -0.140 & -0.285 & -0.021 \\
\hline Parainfluenza virus & $0.473^{* \star}$ & 0.125 & 0.220 & 0.183 \\
\hline RSV & $-0.440 * *$ & -0.219 & $-0.357 *$ & 0.037 \\
\hline Coronavirus & $-0.684 * \star$ & $-0.408 * *$ & $-0.395 * *$ & 0.287 \\
\hline Rhinovirus & -0.096 & $-0.311^{*}$ & -0.163 & $0.368 *$ \\
\hline \multicolumn{5}{|c|}{$\begin{array}{l}\text { The value is the Pearson's correlation coefficient between the number of infectious disease } \\
\text { occurrences and the monthly mean value of meteorological factors. }\end{array}$} \\
\hline
\end{tabular}




\begin{tabular}{|c|c|c|c|c|}
\hline Classification & $\begin{array}{l}\text { Temperature } \\
\left({ }^{\circ} \mathrm{C}\right)\end{array}$ & $\begin{array}{l}\text { Relative } \\
\text { Humidity (\%) }\end{array}$ & $\begin{array}{l}\text { Precipitation } \\
(\mathrm{mm})\end{array}$ & $\begin{array}{l}\text { Particulate Matter } \\
\left(\mathbb{\Xi} / \mathrm{m}^{3}\right)\end{array}$ \\
\hline HBoV & $0.297^{*}$ & -0.125 & 0.061 & $0.366^{*}$ \\
\hline $\begin{array}{l}\text { Human } \\
\text { metaneumovirus }\end{array}$ & -0.279 & $-0.537 * \star$ & -0.277 & $0.511^{* *}$ \\
\hline Echovirus & $0.478 * *$ & $0.402 * \star$ & $0.389 * *$ & $-0.331 *$ \\
\hline Coxsachievirus & $0.654 * *$ & $0.548 * *$ & $0.426 * *$ & $-0.386 * *$ \\
\hline Enterovirus & $0.377 * *$ & $0.395 * *$ & $0.294^{*}$ & $-0.329 *$ \\
\hline Poliovirus & 0.227 & 0.248 & 0.014 & -0.250 \\
\hline untypable & $0.598 * *$ & $0.529 * *$ & $0.513^{* *}$ & $-0.335^{*}$ \\
\hline \multicolumn{5}{|c|}{$\begin{array}{l}\text { The value is the Pearson's correlation coefficient between the number of infectious disease } \\
\text { occurrences and the monthly mean value of meteorological factors. }\end{array}$} \\
\hline \multicolumn{5}{|c|}{$\star P<0.05,{ }^{\star} * P<0.01$, Significant $p$ values in bold. } \\
\hline
\end{tabular}

Viral gastroenteritis pathogens showed opposite correlations with bacterial gastroenteritis pathogens. Rotavirus ( $r=-0.408, p<0.01 ; r=-0.618, p<0.01 ; r=-0.336, p<0.05 ; r=0.321, p<0.05)$ and norovirus $(r=-0.463, p<0.01 ; r=-0.316, p<0.05 ; r=-0.351, p<0.01 ; r=191, p>0.05)$ were observed to have a negative correlation with meteorological factors. However, sapovirus showed a weak positive correlation $(r=0.348$, $p<0.05 ; r=0.379, p<0.01 ; r=0.262, p>0.05 ; r=-0.308, p<0.05)$. Influenza virus $(r=-0.726, p<0.01$; $r=-0.672, p<0.01 ; r=-0.498, p<0.01 ; r=0.478, p<0.01)$, coronavirus $(r=-0.684, p<0.01 ; r=-0.408, p<0.01$; $r=-0.395, p<0.05 ; r=0.287, p>0.05)$, and the pathogens of respiratory infections were prevalent mainly in winter, showing a negative correlation with the meteorological factors. However, parainfluenza virus (PIV) (Temperature: $r=0.473, p<0.01$ ) was positively correlated with temperature, with PIV observed to be prevalent during the high temperature season. Enterovirus pathogens were prevalent in the warm season, and Coxsackievirus showed the highest correlation $(r=0.654, p<0.01 ; r=0.548, p<0.01 ; r=0.426, p<$ $0.01 ; r=-0.386, p<0.01)$

\section{Discussion}

This study was conducted to determine the correlation between the infectious disease outbreak and the climate in Gwangju, Jeollanam-do, Republic of Korea. The four seasons in Korea have distinct characteristics of climate and meteorological factors. Therefore, the climate characteristics of Korea are considered suitable conditions for studying the correlation of pathogens and meteorological factors.

In this study, the highly correlated pathogens were Salmonella, E. coli, Campylobacter jejuni and C. coli, rotavirus, norovirus, influenza virus, coronavirus, and Coxsackievirus. Salmonella, E. coli, and Campylobacter jejuni were observed to have a high incidence during the summer (July-September), wherein the number of infections increased from April and the highest number of cases occurred in 
August. Among the earlier studies that found an association between Salmonella infection and meteorological factors, very high temperatures were found to be a risk factor for contracting Salmonella infection, with more than a six-fold higher risk than that at low temperatures and two-fold higher risk at very high humidity relative to moderate humidity (Wang Pin et al. 2018). In this study, the same result was obtained, with the lowest detection rate of Salmonella in March with eight cases in 4 years, while the most number of detected cases of Salmonella were seen in the month of August with 125 cases yearly (totaling 525 cases). Comparing the meteorological factors between these months, March (temperature $\left.8.6^{\circ} \mathrm{C}, \mathrm{RH} 62.5 \%\right)$ and August $\left(27.6^{\circ} \mathrm{C}, 80 \%\right)$ were statistically different (t-test result, $\left.\mathrm{p}<0.01\right)$. E. coli showed a high correlation with meteorological factors; it was detected the most in August (134 cases, $26.7 \%$ ), and the detection rate was low from November to June (160 cases in 8 months, $31.9 \%$ ). Of the total number of $E$. coli cases detected (502), 68.1\% (342 cases) were detected from July to October. In the study of survival and reproduction of $E$. coli, it was seen that, during the summer season, the temperature rises due to the increase in sunshine, which may promote the growth and aid in the survival of $E$. coli (Perencevich, et al. 2008). Increased water and raw food intake due to high temperatures can also promote bacterial or viral transmission if said food and water is contaminated (D'Souza et al. 2004). Numerous studies have also suggested that precipitation (Gagliardi and Karns 2000; Auld et al. 2004) and relative humidity (Cox 1966) is associated with E. coli outbreaks. Campylobacter jejuni and C. coli showed twice the number of detections in July and August (41 and 41 cases, respectively) compared to other periods, with July and August having much higher rainfall. An earlier study examining the seasonality of $C$. jejuni and $C$. coli has shown that increased precipitation is associated with an increased incidence of campylobacteriosis (Febriani et al. 2010).

Viral gastroenteritis caused by rotavirus (December - May) and norovirus (November - May) occurred more frequently in the dry and cold seasons, with 703 out of 797 cases $(88.2 \%)$ of rotavirus and 768 out of 955 cases $(77.2 \%)$ of norovirus being detected during this season. Thus, the results of this study suggest that rotavirus infection increases as temperature, humidity, and rainfall decrease (Sumi et al. 2013). Additionally, norovirus outbreaks exhibit a clear seasonality with a peak in winter and a trough in summer (winter being Dec-Feb in the Northern Hemisphere, Jun-Aug in the Southern Hemisphere) (Ahmed et al. 2013).

Viral respiratory infections showed high seasonality (Table 3), among which, influenza virus showed the highest correlation and number of seasonal detections (Fig. 1). Seasonal epidemics of the influenza virus are well documented, with influenza virus prevalence and average temperature having a negative correlation. On the other hand, PM10 has a positive correlation with influenza cases (Li et al. 2020), and numerous other studies have reported negative correlations between temperature and the prevalence of the influenza virus (Cao et al. 2010; Xu et al. 2013; Wang et al. 2017). In addition, coronaviruses also show a characteristic seasonality, which occurs mostly in winter and spring, according to a study conducted in adults (Hendley et al. 1972), and human coronavirus 229E in aerosol form is generally less stable at high humidity (ljaz et al. 1985). Coronavirus infection risk has been reported even in tropical regions due to humidity, and in the well-equipped air-conditioned environment, such as hotels and hospitals, there was observed to be an epidemic risk of increased incidence of SARS (KUNLin et al. 2006). 
Likewise, in our study, it was observed that the outbreak of influenza virus showed a negative correlation in response to precipitation and humidity.

Enteroviruses belong to the family Picornaviridae, and is classified into approximately 70 species according to their serotype. Polioviruses are classified into poliovirus and non-poliovirus because of its clinical importance, and can be subdivided into Coxsackie virus group A, group B, echovirus, and enterovirus of various serotypes (Bennett et al. 2000). The targets of the Sentinel Surveillance System are Enterovirus infections, specifically those causing hand, foot, and mouth disease; poliovirus is constantly monitored as a statutory infectious disease. In this study, in the correlation analysis, enteroviruses showed a positive correlation with meteorological factors, excluding particulate matter. In particular, the Coxsackie virus was prevalent with 373 detected cases (88.8\%) between May and September, with an average monthly temperature of $19.6^{\circ} \mathrm{C}$ or higher, and a high correlation being observed. For comparison, the month when the detection of Coxsackie virus was less than 10 was from November to April, with an average temperature of $10^{\circ} \mathrm{C}$ or less. Enterovirus occurs frequently from summer to early autumn and shows the highest incidence rate in August, showing remarkable seasonality (Abedi et al. 2018). The summer-fall seasonality in Coxsackie virus detection was more prominent than for most other serotypes (Khetsuriani et al. 2006), and the mean relative humidity and mean temperature were the only factors found to be independently associated with EV71 infection (Chang et al. 2012). Enterovirus seasonality, which was observed in our study, has also been reported in numerous studies.

In this study, published data were used and had certain limitations: adenovirus, human respiratory syncytial virus (RSV), human rhinovirus (HRV), human metapneumovirus (HMPV), parainfluenza virus (PIV), and human bocavirus (HBoV) were associated with some meteorological factors, but no distinct seasonality was observed. The earlier studies published on these pathogens stated the following: Adenovirus has a high survival rate at high humidity and at a temperature of about $9^{\circ} \mathrm{C}$, making it difficult to detect seasonality. PIV increases at $9.4^{\circ} \mathrm{C}$ and low humidity (Price et al. 2019), and, as for HRV, HRV-A was found steadily throughout the year in the sputum intensive test, HRV-B was found mainly in summer, and HRV-C was found mainly in winter (Ikäheimo et al. 2016). HMPV peaks in early spring, when the infection prevalence is low, and the epidemic occurs every other year in some European countries (Price et al. 2019). HBoV has a seasonality that is prevalent in the cold season (Manning et al. 2006; Jacques et al. 2008), but no distinct seasonality of HBoV was seen in subtropical and tropical (India) climates (Bharaj et al. 2010; Xu et al. 2012). We analyzed the reason for the difference in results of previous studies; we found a possibility of an interference factor (e.g., increased mask wearing rate owing to fine dust) or this difference might have been due to events unknown during the analysis period (e.g., large population infection).

\section{Conclusion}

Our study suggests that some gastroenteritis cases (bacteria and viruses), viral respiratory infections, and enterovirus infections have seasonal pathogens due to meteorological factors. In particular, viral diseases show prominent seasonality, and further studies are needed to confirm this phenomenon. Due to the 
current pandemic of COVID-19, quarantine and prevention have become important in blocking the spread of infectious diseases. For this purpose, research that analyzes and predicts infectivity through various types of data related to infection is important. We are creating a quarantine model that responds to the current pandemic and new infectious diseases that may occur in the future. As in this study, a study to understand the characteristics of infectious diseases depending on meteorological factors is considered necessary as basic data.

\section{Declarations}

\section{Compliance with Ethical Standards}

Competing interests: The authors declare that they have no competing interests.

Funding: None

Ethics approval and consent to participate: This study did not involve any human experimentation and was conducted using publicly available data. This study was approved by the Institutional Review Board of Dankook University (No.2021-03-060) and conducted in accordance with the Declaration of Helsinki.

Consent for publication: Not applicable.

Availability of data and materials: The data that support the findings of this study are available from Portal of the Korea Disease Control and Prevention Agency. The datasets used and/or analyzed during the current study are available from the corresponding author on reasonable request.

Authors' contributions: JK Kim and YH Joung made substantial contributions to the conception or design of the study.JM Kim, YH Joung and Taesu Jang made substantial contributions to the acquisition and analysis of data. We agree to be accountable for all aspects of the study in ensuring that questions related to the accuracy or integrity of any part of the work are appropriately investigated and resolved.

Acknowledgements: None

\section{References}

1. Abedi GR, Watson JT, Nix WA, Oberste MS, Gerber SI (2018) Enterovirus and parechovirus surveillance-United States, 2014-2016. MMWR Morb Mortal Wkly Rep 67(18):515-518. https://doi.org/10.15585/mmwr.mm6718a2

2. Ahmed SM, Lopman BA, Levy K (2013) A systematic review and meta-analysis of the global seasonality of Norovirus. PLOS ONE 8:e75922. https://doi.org/10.1371/journal.pone.0075922

3. Auld H, Maclver D, Klaassen J (2004) Heavy rainfall and waterborne disease outbreaks: The Walkerton example. J Toxicol Environ Health A 67:1879-1887.

https://doi.org/10.1080/15287390490493475

Page 14/18 
4. Bennett JE, Dolin R, Blaser MJ (2014) Mandell, Douglas, and Bennett's principles and practice of infectious diseases: 2-volume set, vol 2. Elsevier Health Sciences, Philadelphia

5. Bharaj P, Sullender WM, Kabra SK, Broor S (2010) Human bocavirus infection in children with acute respiratory tract infection in India. J Med Virol 82:812-816. https://doi.org/10.1002/jmv.21637

6. Campbell-Lendrum D, Wheeler N, Maiero M et al (2018) World Health Organization COP24 special report on health and Climate. Change World Health Organization

7. Cao Z, Zeng D, Wang F, Wang Q, Wang X, Wang J, Zheng X (2010) Weather conditions and spatiotemporal spreading risk of the Beijing 2009 influenza A (H1N1) epidemic. Sci Technol Rev 28:26-32

8. Chang HL, Chio CP, Su HJ, Liao CM, Lin CY, Shau WY, Chi YC, Cheng YT, Chou YL, Li CY, Chen KL, Chen KT (2012) The association between enterovirus 71 infections and meteorological parameters in Taiwan. PLOS ONE 7:e46845. https://doi.org/10.1371/journal.pone.0046845

9. Cox CS (1966) The survival of Escherichia coli sprayed into air and into nitrogen from distilled water and from solutions of protecting agents, as a function of relative humidity. J Gen Microbiol 43:383399. https://doi.org/10.1099/00221287-43-3-383

10. Febriani Y, Levallois P, Gingras S, Gosselin P, Majowicz SE, Fleury MD (2010) The association between farming activities, precipitation, and the risk of acute gastrointestinal illness in rural municipalities of Quebec, Canada: A cross-sectional study. BMC Public Health 10:48. https://doi.org/10.1186/1471-2458-10-48

11. Gage KL, Burkot TR, Eisen RJ, Hayes EB (2008) Climate and vectorborne diseases. Am J Prev Med 35:436-450. https://doi.org/10.1016/j.amepre.2008.08.030

12. Gagliardi JV, Karns JS (2000) Leaching of Escherichia coli 0157: H7 in diverse soils under various agricultural management practices. Appl Environ Microbiol 66:877-883.

https://doi.org/10.1128/AEM.66.3.877-883.2000

13. Hendley JO, Fishburne HB, Jack M, Gwaltney Jr (1972) Coronavirus infections in working adults: eight-year study with 229 E and OC 43. Am Rev Respir Dis 105:805-811. doi 10.1164/arrd.1972.105.5.805

14. ljaz MK, Brunner AH, Sattar SA, Nair RC, Johnson-Lussenburg CM (1985) Survival characteristics of airborne human coronavirus 229E. J Gen Virol 66:2743-2748. https://doi.org/10.1099/0022-131766-12-2743

15. Ikäheimo TM, Jaakkola K, Jokelainen J, Saukkoriipi A, Roivainen M, Juvonen R, Vainio O, Jaakkolo JJK (2016) A decrease in temperature and humidity precedes human rhinovirus infections in a cold climate. Viruses 8:244. https://doi.org/10.3390/v8090244

16. Jacques J, Moret H, Renois F, Leveque N, Motte J, Andreoletti L (2008) Human bocavirus quantitative DNA detection in French children hospitalized for acute bronchiolitis. J Clin Virol 43:142-147. https://doi.org/10.1016/j.jcv.2008.05.010

17. Jones KE, Patel NG, Levy MA, Storeygard A, Balk D, Gittleman JL, Daszak P (2008) Global trends in emerging infectious diseases. Nature 451:990-993. DOI:10.1038/nature06536 
18. Khetsuriani N, Lamonte-Fowlkes A, Oberst S, Pallansch MA, Centre for Disease Control and Prevention (2006) Enterovirus surveillance-United States, 1970-2005. MMWR Surveill Summ 55:120. https://doi.org/10.1037/e540562006-001

19. Lafferty KD (2009) The ecology of climate change and infectious diseases. Ecology 90:888-900. https://doi.org/10.1890/08-0079.1

20. Li Y, Ye X, Zhou J, Zhai F, Chen J (2020) The association between the seasonality of pediatric pandemic influenza virus outbreak and ambient meteorological factors in Shanghai. Environ Health 19:71. https://doi.org/10.1186/s12940-020-00625-7

21. Lin KUN, Yee-Tak Fong D, Zhu B, Karlberg J (2006) Environmental factors on the SARS epidemic: Air temperature, passage of time and multiplicative effect of hospital infection. Epidemiol Infect 134:223-230. https://doi.org/10.1017/S0950268805005054

22. Manning A, Russell V, Eastick K, Leadbetter GH, Hallam N, Templeton K, Simmonds P (2006) Epidemiological profile and clinical associations of human bocavirus and other human parvoviruses. J Infect Dis 194:1283-1290. https://doi.org/10.1086/508219

23. McMichael AJ, Woodruff RE, Hales S (2006) Climate change and human health: Present and future risks. Lancet 367:859-869. DOI:10.1016/S0140-6736(06)68079-3

24. Money P, Kelly AF, Gould SWJ, Denholm-Price J, Threlfall EJ, Fielder MD (2010) Cattle, weather and water: Mapping Escherichia coli 0157: H7 infections in humans in England and Scotland. Environ Microbiol 12:2633-2644. https://doi.org/10.1111/j.1462-2920.2010.02293.x

25. Nakamura I, Takahashi H, Sakagami-Tsuchiya M, Machida M, Sato S, Watanabe Y, Fujita H, Kobayashi T, Fukushima S, Watanabe H (2021) The seasonality of peripheral venous catheter-related bloodstream infections. Infect Dis Ther 10:495-506. https://doi.org/10.1007/s40121-021-00407-9

26. Perencevich EN, McGregor JC, Shardell M, Furuno JP, Harris AD, Morris JG, Fisman DN, Johnson JA (2008) Summer peaks in the incidences of gram-negative bacterial infection among hospitalized patients. Infect Control Hosp Epidemiol 29:1124-1131. https://doi.org/10.1086/592698

27. Price RH (2019) Macgregor, Catriona Graham, and Sandeep Ramalingam Association between viral seasonality and meteorological factors. Sci Rep 9:1-11. https://doi.org/10.1038/s41598-018-37481y

28. Semenza JC, Menne B (2009) Climate change and infectious diseases in Europe. Lancet Infect Dis 9:365-375. https://doi.org/10.1016/S1473-3099(09)70104-5

29. Sumi A, Rajendran K, Ramamurthy T, Krishnan T, Nair GB, Harigane K, Kobayashi N (2013) Effect of temperature, relative humidity and rainfall on rotavirus infections in Kolkata, India. Epidemiol Infect 141:1652-1661. https://doi.org/10.1017/S0950268812002208

30. U.S. CDC (2019) https://www.cdc.gov/climateandhealth/effects/default.ht. Accessed March 2nd, 2021

31. Wang P, Goggins WB, Chan EYY (2018) Associations of Salmonella hospitalizations with ambient temperature, humidity and rainfall in Hong Kong. Environ Int 120:223-230. https://doi.org/10.1016/j.envint.2018.08.014 
32. Wang XL, Yang L, He DH, Chiu AP, Chan KH, Chan KP, Zhou M, Wong CM, Guo Q, Hu W (2017) Different responses of influenza epidemic to weather factors among Shanghai, Hong Kong, and British Columbia. Int J Biometeorol 61:1043-1053. https://doi.org/10.1007/s00484-016-1284-y

33. WHO, WMO, UNEP (2003) Climate change and human health: Risks and responses. Summary World Health Organization, Geneva. ISBN 924156248 X:16-17

34. World Health Organization (2007) The World Health Report 2007: A Safer Future: Global public health security in the 21st Century World Health Organization, Geneva. ISBN 9789241563444

35. Xu L, He X, Zhang DM, Feng FS, Wang Z, Guan LL, Wu JH, Zhou R, Zheng BJ, Yuen KY, Li MF, Cao KY (2012) Surveillance and genome analysis of human bocavirus in patients with respiratory infection in Guangzhou, China. PLOS ONE 7:e44876. https://doi.org/10.1371/journal.pone.0044876

36. Xu Z, Hu W, Williams G, Clements ACA, Kan H, Tong S (2013) Air pollution, temperature and pediatric influenza in Brisbane, Australia. Environ Int 59:384-388.

https://doi.org/10.1016/j.envint.2013.06.022

\section{Figures}


(a)

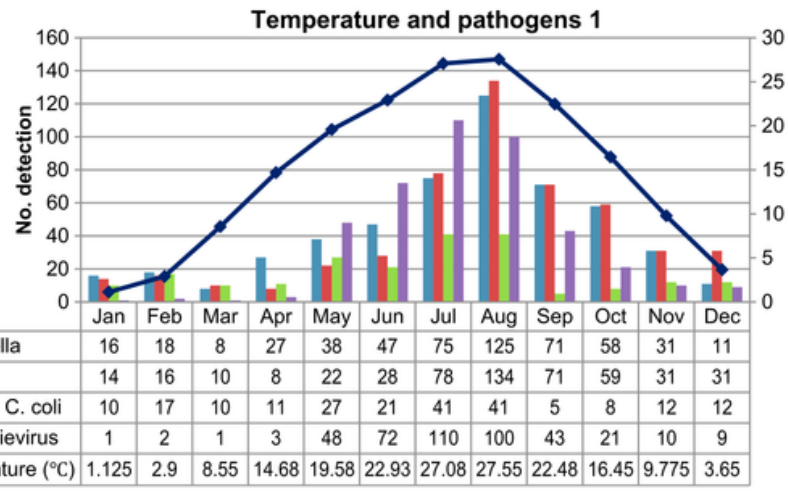

$$
\begin{aligned}
& \text { Salmonella } \\
& =\text { Coxsachievirus coli } \longrightarrow \text { Temperature }\left({ }^{\circ} \mathrm{C}\right)
\end{aligned}
$$

(c)

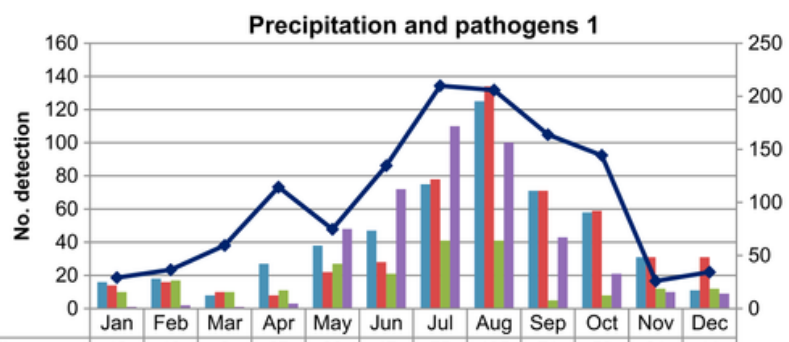

(b)

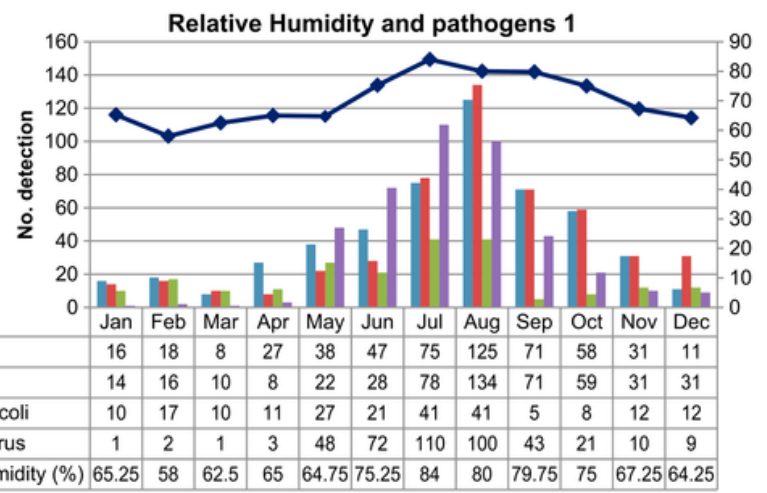

\begin{tabular}{|l|c|c|c|c|c|c|c|c|c|c|c|c|}
\hline Salmonella & 16 & 18 & 8 & 27 & 38 & 47 & 75 & 125 & 71 & 58 & 31 & 11 \\
\hline E. coli & 14 & 16 & 10 & 8 & 22 & 28 & 78 & 134 & 71 & 59 & 31 & 31 \\
\hline C. jejuni, C. coli & 10 & 17 & 10 & 11 & 27 & 21 & 41 & 41 & 5 & 8 & 12 & 12 \\
\hline Coxsachievirus & 1 & 2 & 1 & 3 & 48 & 72 & 110 & 100 & 43 & 21 & 10 & 9 \\
\hline - Relative Humidity (\%) & 65.25 & 58 & 62.5 & 65 & 64.75 & 75.25 & 84 & 80 & 79.75 & 75 & 67.25 & 64.25 \\
\hline
\end{tabular}

$$
\begin{aligned}
& \text { Salmonella } \\
& \text { Coxsachievirus } \quad \longrightarrow \text { Relative Humidity (\%) }
\end{aligned}
$$

(d)

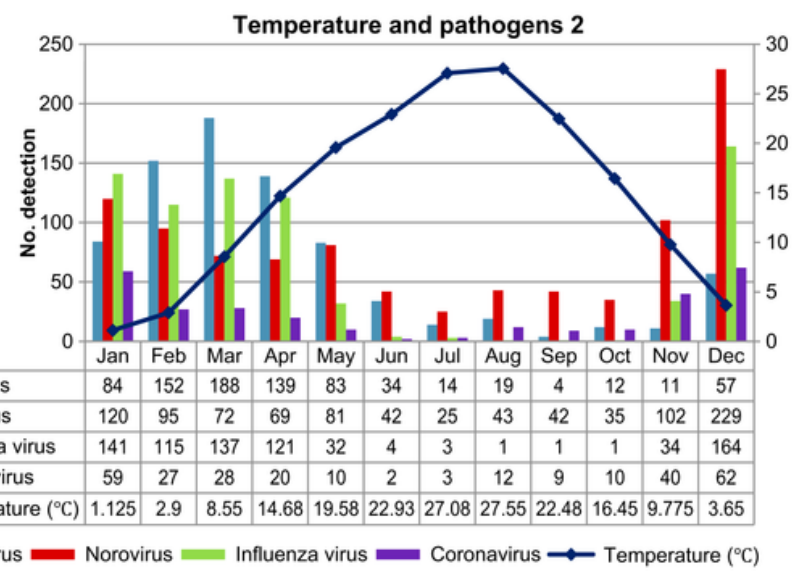

(f)

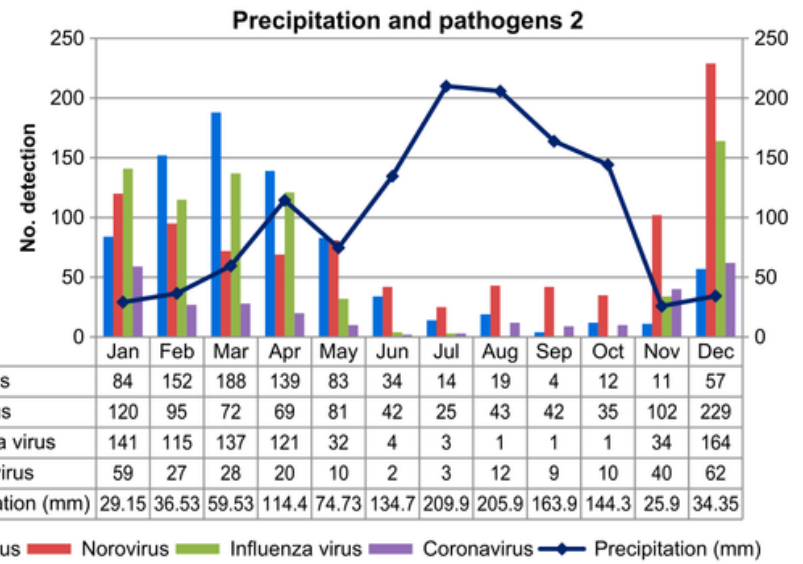

\section{Figure 1}

Variations in meteorological factor and detection rates of major pathogens (2016-2019) 